\title{
Melatonin protects against acrylamide- induced oxidative tissue damage in rats
}

\author{
Ayfer Tozan-Beceren1, Ahmet Özer Şehirli², Emel Eksioglu-Demiralp³, Göksel Şener², \\ Gülden Zehra Omurtag1
}

ABSTRACT: Acrylamide (ACR), is a widely used industrial chemical which induces oxidative stress in the body. In this study we aimed to investigate the possible protective effect of melatonin (MEL), as an antioxidant agent, against experimental ACR toxicity in the liver and kidney of the rats. Wistar albino rats of either sex 200-250 $\mathrm{g}$ were divided into four groups each consisting of 6 animals. Rats received for 10 days; 1 ) $0.9 \% \mathrm{NaCl}$ i.p.; control (C) group; 2) MEL in a dose of $10 \mathrm{mg} / \mathrm{kg}$ i.p., 3) ACR in a dose of $40 \mathrm{mg} / \mathrm{kg}$ i.p. (dissolved in $0.9 \% \mathrm{NaCl}$ ) (ACR group) and 4) MEL (in a dose of $10 \mathrm{mg} / \mathrm{kg}$ i.p.) and ACR (in a dose of $40 \mathrm{mg} / \mathrm{kg}$ i.p.). After decapitation, liver and kidney tissues were excised. Malondialdehyde (MDA), glutathione (GSH) levels, collagen contents and myeloperoxidase activity (MPO) were determined in the tissues, while enzyme activities and cytokine levels were assayed in blood samples. In the ACR treated group, GSH levels decreased significantly while the MDA levels, MPO activity and collagen content increased in the tissues suggesting oxidative organ damage. In the MEL treated ACR group, all of these oxidant responses were reversed significantly. Serum enzyme activities, cytokine levels and leukocyte apoptosis which increased significantly following ACR administration, decreased with MEL treatment. The results demonstrate the role of oxidative mechanisms in ACR-induced tissue damage, and melatonin, by its antioxidant properties, ameliorates oxidative organ injury due to acrylamide toxicity.

KEY WORDS: Acrylamide, melatonin, lipid peroxidation, glutathione, myeloperoxidase

\section{INTRODUCTION}

Acrylamide $\left(\mathrm{CH}_{2}=\mathrm{CH}-\mathrm{CONH}_{2}\right)$ is an $\alpha, \beta$-unsaturated carbonyl compound with a significantly high chemical activity (1). It is extensively used mainly in the manufacture of water-soluble polymers. These polymers are primarily employed by the wastewater, paper, mining, and oil industry (2). ACR does not occur naturally. It was found in various fried, deep-fried and oven-baked foods. It occurs in foods that are regularly consumed throughout the years, not only crisps and bread, but also biscuits, crackers and breakfast cereals. Recent studies demonstrates that acrylamide can also be formed at physiological conditions (37 degrees $\mathrm{C}, \mathrm{pH}$ 7.4) when asparagine is incubated in the presence of hydrogen peroxide $\left(\mathrm{H}_{2} \mathrm{O}_{2}\right)$. Nevertheless, it is presumably not physiologically produced in toxic concentrations $(1,3)$.

Acrylamide is toxic and an irrritant. Cases of acrylamide poisoning show signs and symptoms of local ef- fects due to irritation of the skin and mucous membranes and systemic effects due to the involvement of the central, peripheral, and autonomic nervous systems. Studies of neurotransmitter distribution and receptor binding in the brain of rats have revealed changes induced by acrylamide. In rats, changes in the concentration of neurotransmitters and in striatal dopamine receptor binding have been related to behavioural changes. Degenerative changes in renal convoluted tubular epithelium and glomeruli and fatty degeneration and necrosis of the liver have been seen in monkeys given large doses of acrylamide. In rats, impairment of hepatic porphyrin metabolism has been observed. The toxicity of ACR is at least in part related to free radicals and free radical-mediated oxidative stress. Thus, it would be of therapeutic benefit to develop new drugs that are capable of scavenging these free radicals in the treatment of acrylamide-induced damage (4).
AFFILIATIONS

1 Marmara University, Faculty of Pharmacy, Department of Pharmaceutical Toxicology, İstanbul, Turkey

2Marmara University, Faculty of Pharmacy, Department of Pharmacology, İstanbul, Turkey

3Marmara University, Faculty of Medicine, Department of Hematology-Immunology, isstanbul, Turkey

CORRESPONDENCE

Ayfer Tozan-Beceren

E-mail:

ayfertozan@hotmail.com

Received:

03.07.2012

Revision:

24.07.2012

Accepted:

25.07.2012 
Melatonin, the chief indolamine produced by the pineal gland in all vertebrates and follows a circadian pattern. Melatonin was initially studied in terms of its role in endocrine physiology regulating circadian and, sometimes, seasonal rhythms (5). However, evidence has been accumulated showing that melatonin influences the function of a variety of tissues not related to the endocrine system $(5,6)$ and that it has been played an important role in antioxidant and free radical scavenger (7-10). There is a substantial body of evidence for a protective effect of melatonin and its metabolites against DNA, lipids, and proteins, which are the result of a number of endogenous and exogenous free radical generating processes (11-15). In addition, besides directly neutralizing a number of free radicals and reactive oxygen and nitrogen species, melatonin stimulates several antioxidative enzymes (e.g., superoxide dismutase, glutathione peroxidase and glutathione reductase), which increase its efficiency as an antioxidant. The marked protective effects of melatonin against oxidative stress are aided by its ability to cross all biological membranes. That is, melatonin, may reach to its highest concentrations in the nucleus of the cell where it, protects DNA from free radical damage $(16,17)$.

The view of above findings has inspired us to study the role of oxidative stress and protective effects in acrylamide-induced organ damage and to examine the putative protective effect of melatonin against acrylamide-induced injury in renal and hepatic tissues.

\section{MATERIALS AND METHODS Animals}

All experimental protocols were approved by the Marmara University School of Medicine Animal Care and Use Committee. Wistar albino rats (250-300 g) were housed in a room at a mean constant temperature plus or minus standard error of mean (SEM) of $22 \pm 2{ }^{\circ} \mathrm{C}$ with a 12 hour light-dark cycle, and free access to standard pellet chow and water.

\section{Experimental groups}

Wistar albino rats of either sex 200-250 g were administered acrylamide (Merck, 800830), (40 mg/ kg/day i.p.) followed by either saline (ACR group) or melatonin $(10 \mathrm{mg} / \mathrm{kg} /$ day i. $\mathrm{p}+40$ $\mathrm{mg} / \mathrm{kg} /$ day i.p, respectively, ACR+Mel Group) for ten days. In the control rats saline $(0.9 \% \mathrm{NaCl}$, control group) or Melatonin $(10 \mathrm{mg} / \mathrm{kg} /$ day i.p. MEL group) was injected for ten days, following saline administration (acrylamide vehicle). Each group consists of 6 animals.

The animals were decapitated on the tenth day and trunk blood samples were collected to analyse aspartate aminotransferase (AST), alanine aminotransferase (ALT), blood urea nitrogen (BUN) and creatinine levels, lactate dehydrogenase (LDH) activity, tumor necrosis factor a (TNF-a), interleukin (IL)-1 $\beta$, 8-hydroxydeoxyguanosine (8-OHdG) and total antioxidant capacity (AOC). In the liver, and kidney tissue samples, stored at $-70^{\circ} \mathrm{C}$, malondialdehyde (MDA) levels, an end product of lipid peroxidation, glutathione (GSH), a key antioxidant, and tissue-associated myeloperoxidase (MPO) activity, as indirect evidence of neutrophil infiltration, were measured. Additional tissue samples were placed in formaldehyde $(10 \%)$ for the determination of collagen content. Serum enzyme activities, cytokine levels and leukocyte apoptosis were assayed in plasma samples.

\section{Assays}

Blood urea nitrogen (18) and serum AST, ALT (19) and creatinine (20) concentrations and LDH levels (21) were determined spectrophotometrically using an automated analyzer (Bayer OpeRA biochemical analyzer, Germany). Serum levels of TNF- $\alpha$ and IL-1 $\beta$ were quantified using enzyme-linked immunosorbent assay (ELISA) kits specific for the previously mentioned rat cytokines according to the manufacturer's instructions and guidelines (Biosource Europe S.A., Nivelles, Belgium). The total antioxidant capacity in plasma were measured by using colorimetric test system (ImAnOx, cataloge no. KC5200, Immunodiagnostic AG, D-64625 Bensheim), according to the instructions provided by the manufacturer. The 8 -OHdG content in the extracted DNA solution were determined by enzyme-linked immunosorbent assay (ELISA) method (Highly Sensitive 8-OHdG ELISA kit, Japan Institute for the Control of Aging, Shizuoka, Japan). These particular assay kits were selected because of their high degree of sensitivity, specificity, inter- and intraassay precision and small amount of plasma sample required conducting the assay.

\section{Malondialdehyde and glutathione assays}

Tissue samples were homogenized with ice-cold $150 \mathrm{mM} \mathrm{KCl}$ for the determination of MDA and GSH levels. The MDA levels were assayed for products of lipid peroxidation by monitoring thiobarbituric acid reactive substance formation as described previously (22). Lipid peroxidation was expressed in terms of MDA equivalents using an extinction coefficient of $1.56 \times 10^{5} \mathrm{M}^{-1} \mathrm{~cm}^{-1}$ and results were expressed as nmol MDA/g tissue. Glutathione measurements were performed using a modification of the Ellman procedure (23). Briefly, after centrifugation at $2000 \mathrm{~g}$ for $10 \mathrm{~min}, 0.5 \mathrm{ml}$ of supernatant was added to $2 \mathrm{ml}$ of $0.3 \mathrm{~mol} / 1 \mathrm{Na}_{2} \mathrm{HPO}_{4} \cdot 2 \mathrm{H}_{2} \mathrm{O}$ solution. A 0.2 $\mathrm{ml}$ solution of dithiobisnitrobenzoate $(0.4 \mathrm{mg} / \mathrm{ml} 1 \%$ sodium citrate) was added and the absorbance at $412 \mathrm{~nm}$ was measured immediately after mixing. GSH levels were calculated using an extinction coefficient of $1.36 \times 10^{4} \mathrm{M}^{-1} \mathrm{~cm}^{-1}$. Results were expressed in $\mu \mathrm{mol} \mathrm{GSH} / \mathrm{g}$ tissue.

\section{Myeloperoxidase (MPO) activity and tissue collagen measurement}

$\mathrm{MPO}$, an enzyme of activated polymorphonuclear cells (PMNs), is used as an indication of tissue neutrophil accumulation. Tissue MPO activity was measured using a procedure similar to that documented previously (24). Tissue samples were homogenized in $50 \mathrm{mM}$ potassium phosphate buffer (PB, $\mathrm{pH}$ 6.0), and centrifuged at 41,400 g (10 min); pellets were suspended in $50 \mathrm{mM}$ PB containing $0.5 \%$ hexadecyltrimethylammonium bromide (HETAB). After three freeze and thaw cycles, with sonication between cycles, the samples were centrifuged at $41,400 \mathrm{~g}$ for $10 \mathrm{~min}$. Aliquots $(0.3 \mathrm{ml})$ were added to $2.3 \mathrm{ml}$ of reaction mixture containing $50 \mathrm{mM} \mathrm{PB}$, o-dianisidine, and $20 \mathrm{mM} \mathrm{H}_{2} \mathrm{O}_{2}$ solution. One unit of enzyme activity was defined as the amount of the MPO present that caused a change in absorbance measured at $460 \mathrm{~nm}$ for $3 \mathrm{~min}$. MPO activity was expressed as $\mathrm{U} / \mathrm{g}$ tissue.

Tissue collagen was measured as a free radical-induced fibrosis marker. Tissue samples were cut with a razor blade, immediately fixed in $10 \%$ formalin in $0.1 \mathrm{M}$ phosphate buffer ( $\mathrm{pH}$; 7.2) in paraffin, and approximately $15 \mu \mathrm{m}$ thick sections were obtained. Evaluation of collagen content was based on the method published (25), which is based on selective binding of the dyes Sirius Red and Fast Green FCF to collagen and noncollagenous components, respectively. Both dyes were eluted 
TABLE 1. Serum alanine aminotransferase (ALT) and aspartate aminotransferase (AST), BUN and creatinine levels in the saline- or melatonin-treated control and acrylamide groups. Each group consist of 6 rats. Groups of data were compared with an analysis of variance (ANOVA) followed by Tukey's multiple comparison tests.

\begin{tabular}{lcccc}
\hline & \multicolumn{2}{c}{ Control groups } & \multicolumn{2}{c}{ Acrylamide groups } \\
\hline & Saline-treated & Melatonin-treated & Saline-treated & Melatonin-treated \\
\hline ALT (U/l) & $52.3 \pm 5.3$ & $56.7 \pm 7.5$ & $118 \pm 9.1^{* \star *}$ & $72 \pm 5.1^{++}$ \\
AST (U/l) & $170 \pm 11.2$ & $169 \pm 9.7$ & $394 \pm 34^{* * *}$ & $212 \pm 9.6^{+++}$ \\
BUN (mg/dl) & $22.0 \pm 2.0$ & $21.3 \pm 1.8$ & $83.3 \pm 11.4^{* * *}$ & $31.8 \pm 3.7^{+++}$ \\
Creatinine (mg/dl) & $0.50 \pm 0.08$ & $0.53 \pm 0.08$ & $2.25 \pm 0.24^{* * *}$ & $0.75 \pm 0.09+++$ \\
\hline
\end{tabular}

Data are mean \pm SEM ${ }^{* * *} p<0.001$, compared with saline-treated control group. ${ }^{++} p<0.01,{ }^{+++} p<0.001$ compared with saline-treated acrylamide group.

TABLE 2. Plasma lactate dehydrogenase activity (LDH), tumor necrosis factor-alpha (TNF- $\alpha$ ), interleukin- 1 beta (IL-1 $\beta$ ), 8-hydroxydeoxyguanosine (8-OHdG), levels and antioxidant capacity (AOC) in the saline- or melatonin-treated control and acrylamide groups. Each group consist of 6 rats. Groups of data were compared with an analysis of variance (ANOVA) followed by Tukey's multiple comparison tests.

\begin{tabular}{lcccc}
\hline & \multicolumn{2}{c}{ Control groups } & \multicolumn{2}{c}{ Acrylamide groups } \\
\hline & Saline-treated & Melatonin-treated & Saline-treated & Melatonin-treated \\
\hline $\mathrm{LDH}(\mathrm{U} / \mathrm{l})$ & $2146 \pm 195$ & $2063 \pm 190$ & $4454 \pm 265^{* * *}$ & $2721 \pm 1633^{+++}$ \\
$\mathrm{TNF}-\alpha(\mathrm{pg} / \mathrm{ml})$ & $5.2 \pm 1.1$ & $6.5 \pm 0.9$ & $29.7 \pm 3.7^{* * *}$ & $13.2 \pm 2.3^{+++}$ \\
$\mathrm{IL}-1 \beta(\mathrm{pg} / \mathrm{ml})$ & $18.5 \pm 1.6$ & $16.9 \pm 1.7$ & $55.7 \pm 6.2^{* * *}$ & $24.2 \pm 5.4^{+++}$ \\
$8-\mathrm{OHdG}(\mathrm{ng} / \mathrm{ml})$ & $0.68 \pm 0.05$ & $0.70 \pm 0.07$ & $6.95 \pm 0.24^{* * *}$ & $3.10 \pm 0.18^{* * *},+++$ \\
$\mathrm{AOC}(\mathrm{pg} / \mathrm{ml})$ & $461 \pm 18$ & $466 \pm 17$ & $209 \pm 16^{* * *}$ & $382 \pm 27^{+++}$ \\
\hline
\end{tabular}

Data are mean \pm SEM ${ }^{* * *} p<0.001$ compared with saline-treated control group. $+++p<0.001$ compared with saline-treated acrylamide group.

readily and simultaneously by using $0.1 \mathrm{~N} \mathrm{NaOH}-$ methanol $(1: 1, v / v)$. Finally, the absorbances at 540 and $605 \mathrm{~nm}$ were used to determine the amount of collagen and protein, respectively.

\section{Evaluation Apoptosis and Cell Death (26)}

Erythrocytes from heparinized blood samples of the groups were discarded using Flow Cytometric. White blood cells were washed and re-suspended in PBSG. Two tubes were prepared for each apoptosis experiments and $1 \times 10^{5}$ cells $/ \mathrm{ml}$ were distributed into the tubes. One was induced for apoptosis using $100 \mathrm{ng} / \mathrm{ml}$ of PMA at $37^{\circ} \mathrm{C}$ for 2 hours, while other was incubated at the same temperature without stimulation, as a control. To demonstrate early apoptosis, cells were washed with PBS following stimulation and were labeled with annexin V according to manufacturer's instructions (Biovision, Mountain view, CA). Briefly $1 \mu \mathrm{l}$ of annexin $\mathrm{V}$ was added to the tubes and cells were incubated at dark for 15 minutes. Once propidium iodide $(20 \mathrm{ng} / \mathrm{ml})$ was added to label late apoptosis and cell death, cells were acquired by flow-cytometry. For analysis, lymphocytes and neutrophils were separately gated according to their granularity and size on forward scatter (FSC) versus Side Scatter (SSC) plot. Early apoptosis, late apoptosis, necrosis and cell death were evaluated on Fluorescence 1 (FL1 for annexin V) versus Fluorescence 3 (FL3 for propidium iodide) plots. Apoptosis and cell death ratios were calculated by dividing the values of after-stimulation to the values obtained prior to stimulation.

\section{Statistics}

Statistical analysis was carried out using GraphPad Prism 3.0 (GraphPad Software, San Diego; CA; USA). Each group consisted of 6 animals. All data were expressed as means \pm SEM. Groups of data were compared with an analysis of variance (ANOVA) followed by Tukey's multiple comparison tests. Values of $\mathrm{p}<0.05$ were regarded as significant.

\section{RESULTS}

As an indication of hepatic injury, AST and ALT levels were significantly higher in the saline-treated acrylamide group when compared with those of the control groups $(\mathrm{p}<0.001)$. Melatonin treatment decreased both AST and ALT levels significantly ( $p<0.01-0.001)$ and almost back to the control values. BUN and creatinine concentrations were studied to assess the renal functions. As shown in Table 1, although there is no statistical significance between the control and melatonin groups, BUN levels were tended to increase by ACR treatment due to melatonin administration prevented this increases. On the other hand serum creatinine levels in the saline-treated acrylamide group were found to be significantly higher than the control rats $(\mathrm{p}<0.001$, Table 1$)$. When melatonin was administered concomitantly with acrylamide, elevation in creatinine levels was prevented $(\mathrm{p}<0.001)$.

Serum LDH activity, as an indicator of generalized tissue damage showed a significant increase in the acrylamide group $(p<0.001)$, and this effect was significantly suppressed by melatonin treatment $(\mathrm{p}<0.001$, Table 2$)$. In the saline-treated acrylamide group plasma TNF- $\alpha$, IL-1 $\beta$ and $8-\mathrm{OH} d G$, as an indicator of oxidative DNA damage, levels were significantly increased as compared to control group $(p<0.001)$. Plasma AOC were decreased and these ACR-induced rises in plasma cytokines and decrease in AOC were significantly reversed with melatonin treatment $(\mathrm{p}<0.05-0.001$, Table 2$)$.

Annexin V stainings alone were evaluated as early apoptosis, while annexin $\mathrm{V}$ along with propidium iodide stainings were evaluated as late apoptosis. Early apoptosis ratio in neutrophils was significantly higher in the control rats when compared to other groups $(\mathrm{p}<0.001$; Figure 1a). Similar results were obtained in the early apoptosis of control lymphocytes compared to the other groups $(\mathrm{p}<0.001$; Figure 2a). Accordingly, late apoptosis of neutrophils and lymphocytes were sig- 
a)

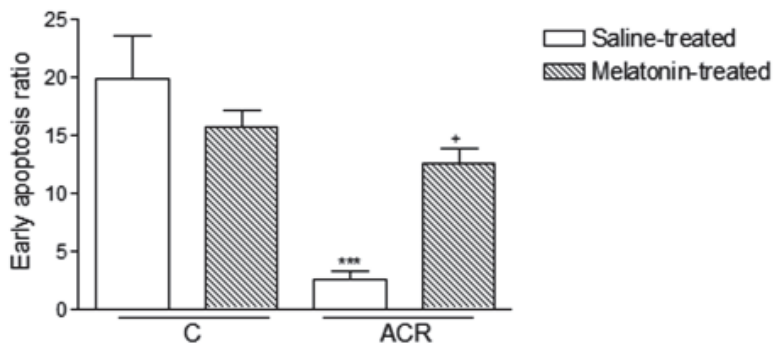

b)

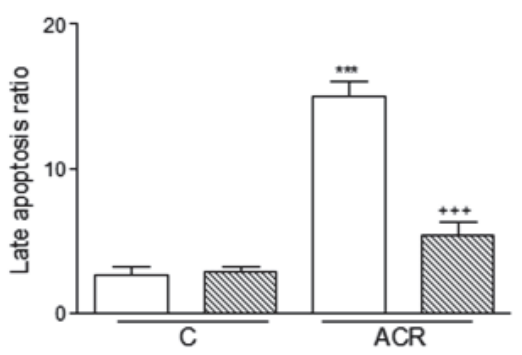

c)

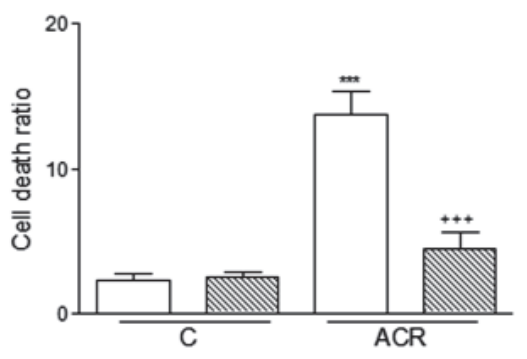

FIGURE 1. a) Early apoptosis, b) late apoptosis, and c) cell death in neutrophils in blood samples of saline- or melatonin-treated control and acrylamide groups. Apoptosis and cell death ratios were calculated by dividing the values of afterstimulation to the values obtained prior to phorbol myristate acetate stimulation. ${ }^{* * *} \mathrm{p}<0.001$ compared to saline-treated control group; ${ }^{+} \mathrm{p}<0.05,{ }^{+++} \mathrm{p}<0.001$, compared to saline-treated acrylamide group.

nificantly increased in rats injected with ACR $(\mathrm{p}<0.001)$, while melatonin administration abolished the apoptotic effect of ACR on neutrophils $(p<0.05$ and $p<0.001$; Figure $1 b$ and Figure $2 b)$. In addition, ACR significantly induced cell death $(\mathrm{p}<0.001)$ and melatonin prevented the cell death ratio in both neutrophils and lymphocytes $(p<0.05$ and $p<0.01)$ (Figure $1 c$ and Figure $2 \mathrm{c}$ ).

MDA levels determined in the liver and kidney tissues were found to be significantly higher in the saline-treated ACR group than those in the control groups $(p<0.001)$, while treatment with melatonin reversed this effect, bringing the MDA levels back to the control values ( $p<0.001$; Figure 3 ). On the other hand, GSH levels in both tissues studied were significantly decreased due to ACR administration ( $\mathrm{p}<0.001)$, and melatonin treatment inhibited the depletion of GSH stores $(\mathrm{p}<0.001)$ (Figure 4). a)

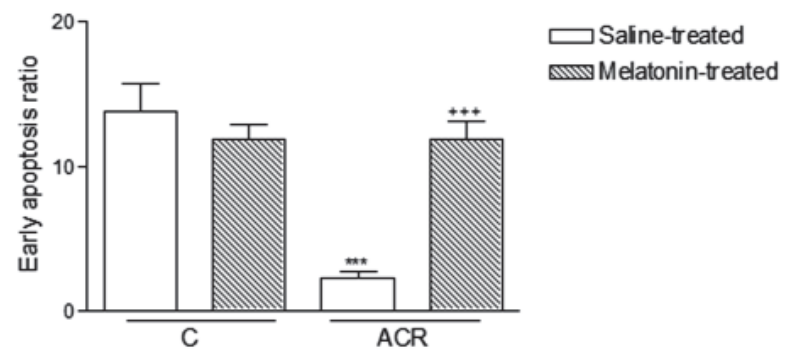

b)

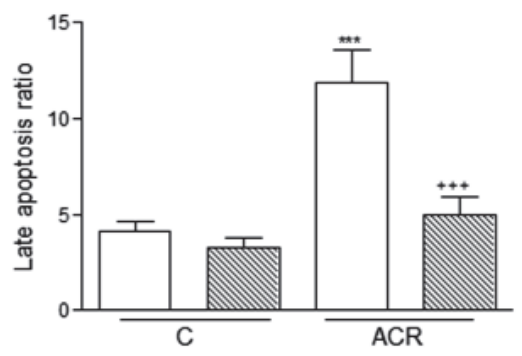

c)

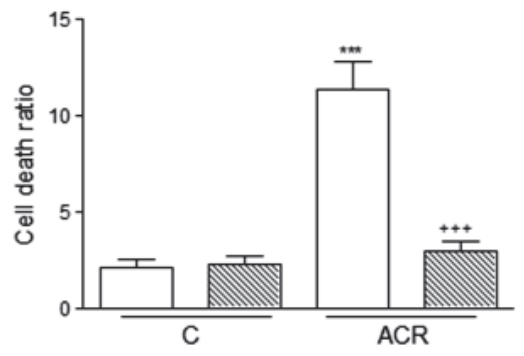

FIGURE 2. a) Early apoptosis, b) late apoptosis, and c) cell death in lymphocytes in blood samples of saline- or melatonin-treated control and acrylamide groups. Apoptosis and cell death ratios were calculated by dividing the values of after-situmulation to the values obtained prior to phorbol myristate acetate stimulation. ${ }^{* * *} p<0.001$ compared to saline-treated control group; ${ }^{+++} p<0.001$, compared to saline-treated acrylamide group.

In the saline-treated ACR group, MPO activities in the liver and kidney tissues were found to be increased significantly $(p<0.001)$. On the other hand treatment with melatonin reversed these elevations ( $p<0.001$; Figure 5$)$. As an indicator of enhanced tissue fibrotic activity, the collagen contents in the liver and kidney demonstrated significant increases in salinetreated ACR group $(\mathrm{p}<0.001)$; melatonin treatment prevented these alterations in the both tissues significantly $(p<0.001$; Figure 6).

\section{DISCUSSION}

In the present study, increases in malondialdehyde levels, myeloperoxidase activity and collagen content as well as the decrease in glutathione levels induced by ACR were prevented by melatonin treatment, demonstrating that ACR caused oxidative organ injury in the liver and kidney tissues were ameliorated by antioxidant melatonin 


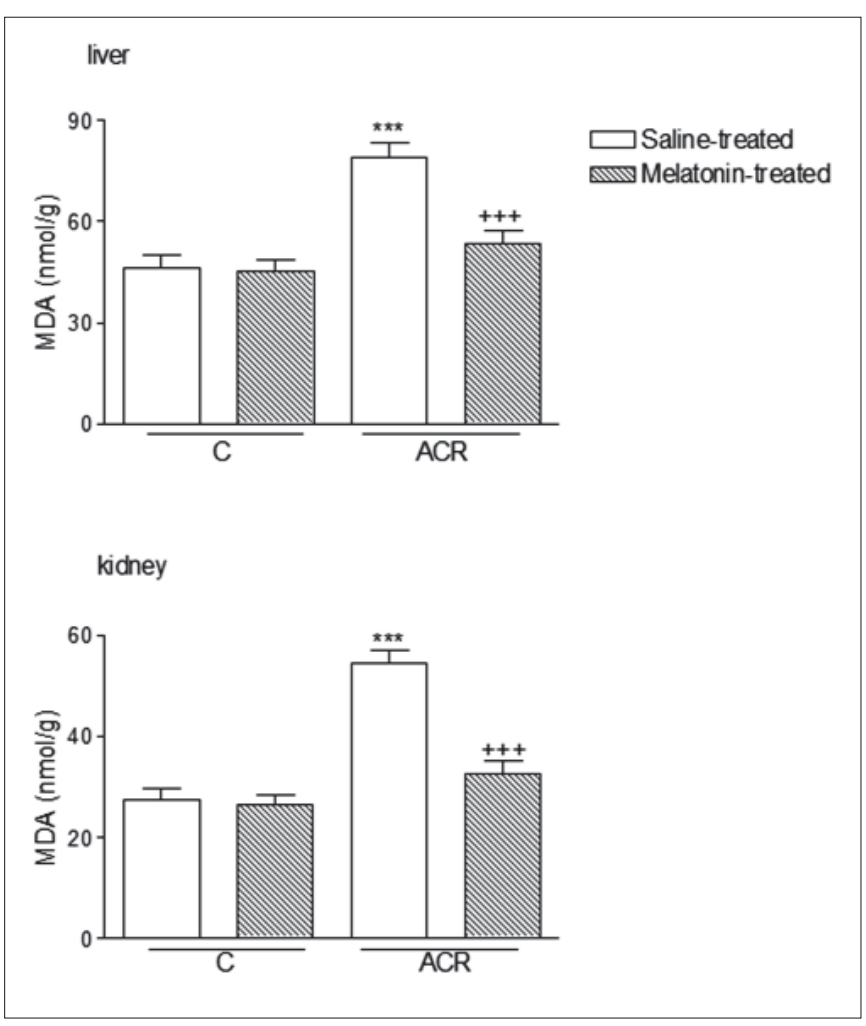

FIGURE 3. Malondialdehyde (MDA) levels in the liver and kidney samples of saline- or melatonin-treated control and acrylamide (ACR) groups. ${ }^{* \star *} \mathrm{p}<0.001 \mathrm{com}$ pared to saline-treated control group. ${ }^{+++} p<0.001$ compared to saline-treated acrylamide group. Each group consist of 6 rats.

treatment. Moreover, impairments in hepatic and renal functions due to ACR were also improved by melatonin treatment, and plasma levels of the proinflammatory cytokines TNF- $\alpha$ and IL-1 $\beta, 8-\mathrm{OHdG}$ and oxidative DNA damage were reduced. These findings suggest that melatonin may be protective against ACR-induced oxidative injury by inhibiting neutrophil infiltration, and subsequent activation of inflammatory mediators that induce lipid peroxidation.

Acrylamide is a small, reactive conjugated vinyl compound. After consumption, it is absorbed in the circulation and distributed to various organs, where it can react with DNA, neurons, hemoglobin, and essential enzymes (27). In the present study, we provide experimental evidence in support of the role of oxidative stress in ACR toxicity.

In macrophages, nuclear factor $\mathrm{\kappa B}(\mathrm{NF}-\mathrm{\kappa} B)$ in cooperation with other transcription factors coordinates the expression of genes encoding both iNOS and TNF-a. NF-kB plays a critical role in the activation of immune cells by upregulating the expression of many cytokines essential to the immune response (28). In particular, NF-kB stimulates the production of IL-1, IL-6, TNF-a, lymphotoxin, and IFN-Y (29) These cytokines play important roles in the induction of PMN activation and infiltration and induce not only localized tissue injury, but also remote organ injury (30). In accordance with these findings, in the present study, the plasma levels of the pro-inflammatory cytokines TNF- $\alpha$, and IL-1 $\beta$ were significantly elevated in ACR-induced hepatorenal injury, which was verified using

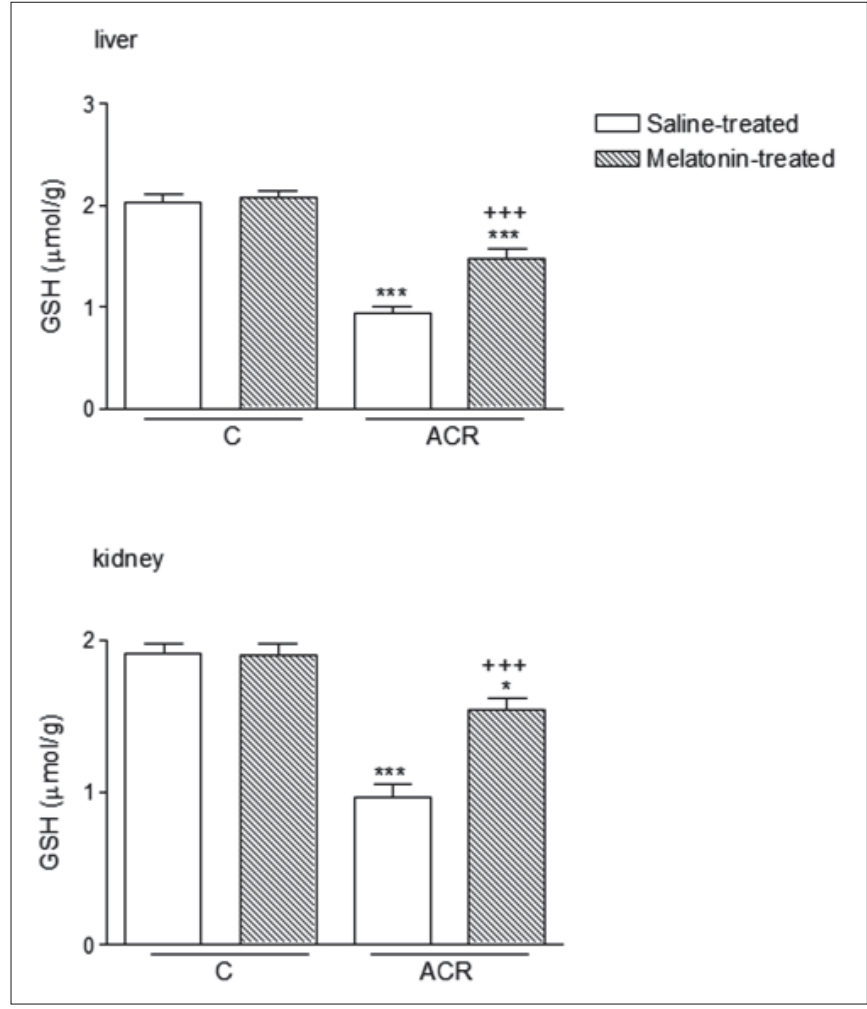

FIGURE 4. Glutathione (GSH) levels in the liver and kidney samples of saline- or melatonin-treated control and acrylamide (ACR) groups. ${ }^{*} p<0.05,{ }^{* * *} p<0.001$ compared to saline-treated control group. ${ }^{+++} p<0.001$ compared to saline-treated acrylamide group. Each group consist of 6 rats.

biochemical assessment. Furthermore, melatonin reversed all these parameters of injury and the levels of the inflammatory mediators while protecting the renal tissue against reperfusion-induced oxidative injury.

It is well known that increased ROS generation may cause a significant amount of single-strand DNA breaks which activate the nuclear poly (ADP-ribose) polymerase (PARP), a chromatin-bound enzyme involved in the repair of DNA breaks (31). However, activation of the nuclear PARP accelerates NAD+ catabolism and depletion of NAD+ compromises the mitochondrial energy metabolism, which contributes to the toxicity of ACR (32). 8-OHdG is one of the most common adducts formed by oxidative DNA damage (33) and a reliable marker of oxidative DNA damage (34). The present results demonstrate that ACR treatment leads to a highly elevated plasma level of $8-O$ OhdG, which is reduced when the rats are treated with melatonin. Thus, ACR-induced toxicity appears to be alleviated by melatonin through a mechanism that involves the protection against oxidative DNA damage and associated changes in mitochondrial energy metabolism.

The result of oxygen radical formation is damage to an array of biomolecules found in tissues, including nucleic acids, membrane lipids, enzymes, and receptors. Membrane-associated polyunsaturated fatty acids are readily attached by $\bullet \mathrm{OH}$ in a process that leads to peroxidation of lipids, which can disrupt membrane fluidity and cell compartmentation, resulting in cell lysis (35). Thus in rats ACR exposure 


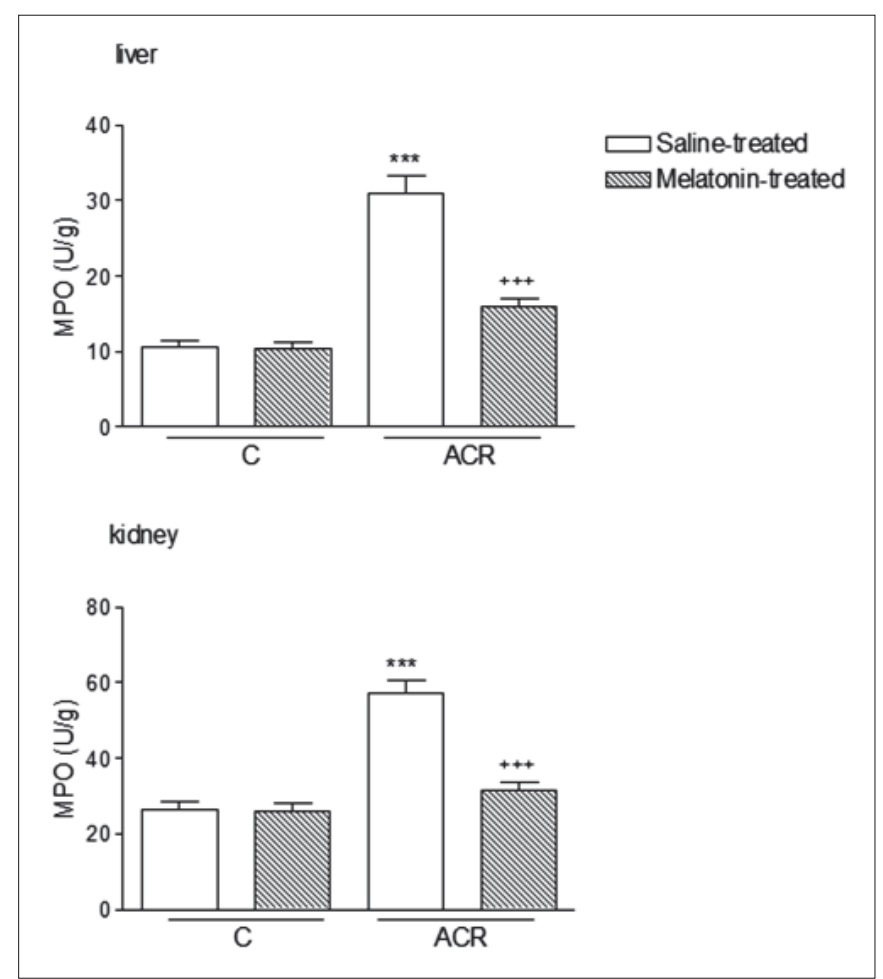

FIGURE 5. Myeloperoxidase activity (MPO) in the liver and kidney samples of saline- or melatonin-treated control and acrylamide (ACR) groups., ${ }^{* * *}: p<0.001$ compared to saline-treated control group., $+++: p<0.001$ compared to salinetreated acrylamide group. Each group consist of 6 rats.

generating oxidative stress, may contribute to the impaired cellular function of the liver and kidney. In the present study, ACR caused significant increases in the hepatic and renal malondialdehyde levels, end products of lipid peroxidation, where function of these organs were also impaired as demonstrated by increased ALT, AST and creatinine levels.

It is shown that hepatic and renal tissues produce large amounts of ROS at ACR toxicity in rats (1) highly reactive ROS directly attacks lipids, proteins in the biological membranes and cause their dysfunction (36). Peroxidation of lipid membranes, disintegration of cytoskeleton and intracellular compartments by ROS might lead to the disturbances of digestive and lizosomal enzymes transport within the cell leading to the cell damage (37). Degradation of polyunsaturated fatty acids in cell membranes by ROS results in the destruction of membranes and formation of thiobarbituric acid reactive substances, MDA or conjugated dienes as indicator of lipid peroxidation in the course of ACR toxicity (1). Knowledge of the absorption and metabolism of exogenous indoleamine drug becomes essential before any conclusions may be drawn regarding its potential to exert biological activity in vivo, as suggested by in vitro studies. Melatonin owes its free radical-scavenging property to the methoxy group at position- 5 of the indole nucleus and the acetyl group of the side chain of melatonin (38). In accordance with these findings, in the present study the increased lipid peroxidation in the hepatorenal tissues, as demonstrated by MDA assay, was also reversed with melatonin treatment, emphasizing the antioxidant action of melatonin on

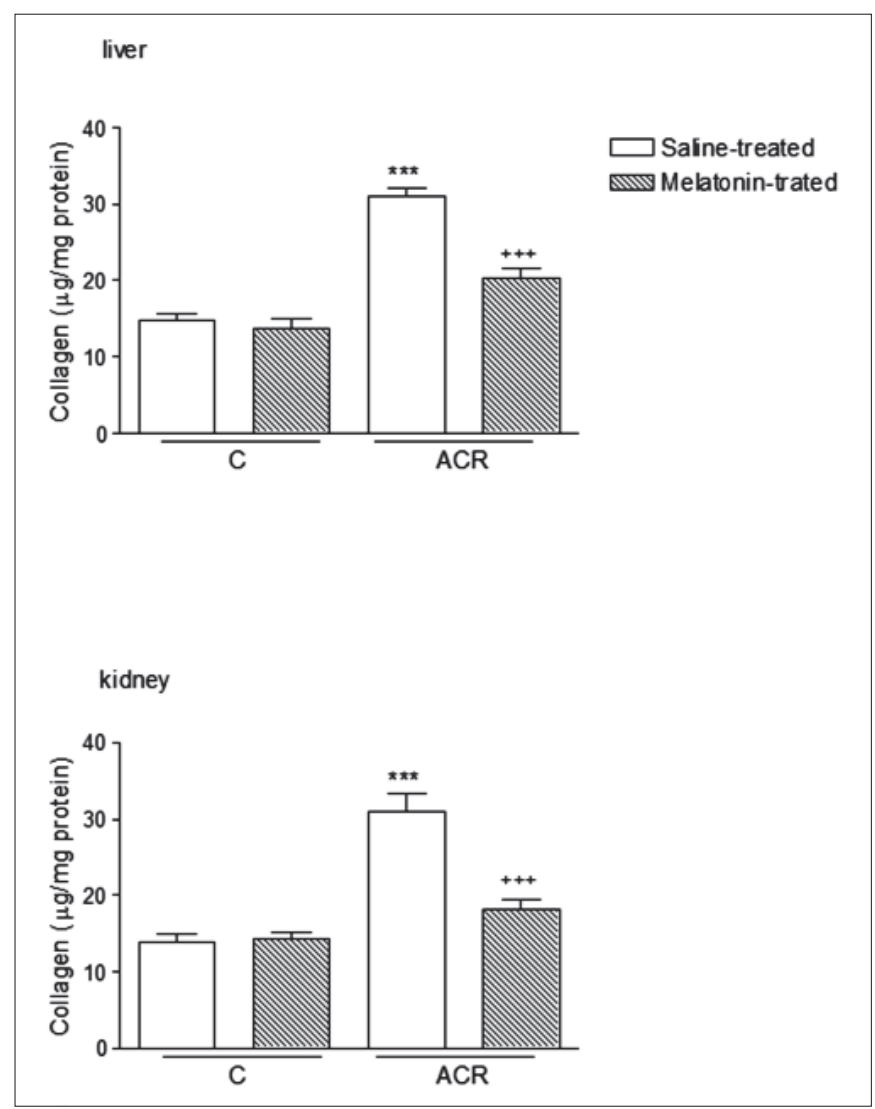

FIGURE 6. Collagen content in the liver and kidney samples of saline- or melatonin-treated control and acrylamide (ACR) groups. ${ }^{* \star *} \mathrm{p}<0.001$, compared to saline-treated control group. ${ }^{+++} p<0.001$, compared to saline-treated acrylamide group. Each group consist of 6 rats.

the deleterious consequences of reactive oxygen metabolites (ROMs) in oxidative ACR toxicity.

GSH is a major intracellular antioxidant as well as an important component in the metabolism of many xenobiotics, including ACR (39). Both GSH functions can indeed be important for mitigation of ACR toxicity in an in vivo exposure scenario. In fact, besides the possibility of ACR being an oxidative stress inducer and this compound is efficiently conjugated with reduced glutathione (GSH) (40). Cellular oxidative stress can either lead to or indicate a depletion of GSH and may lead to apoptosis, cell proliferation, or transformation (41). This may explain significantly increased leukocyte apoptosis following ACR administration in our present study. Therefore, by depleting intracellular GSH, glutathione-ACR adduct formation can favor cellular oxidative stress, which may be one possible mechanism governing ACR toxicity $(42,43)$.

Generally, the antioxidant and antitoxic effects of SH-containing amino acids, peptides, and proteins are due to several mechanisms including their ability to act as precursors of GSH, reducing agents, scavengers of reactive oxygen species, strong nucleophiles that can trap electrophiles such as ACR, thus preventing biological alkylation of DNA, and inducers of cellular detoxification $(28,44)$. Melatonin is a well known direct free radical scavenger and besides directly neutralizing a number of free radicals and reactive oxygen and nitrogen species, it stimulates several antioxidative enzymes 
such as superoxide dismutase, glutathione peroxidase and glutathione reductase which increase its efficiency as an antioxidant $(45,46)$. Thus, melatonin may be important in determining GSH homeostasis within the cell and may also determine the total amount of GSH within the cell. Since it was also shown to stimulate $\gamma$-glutamylcysteine synthethase, it can be stated that, as well as recycling of GSH in the cell, it also influences the synthesis of GSH, thus having an important role in the maintenance of this crucial antioxidant (16).

Free radicals, besides their direct damaging effects on tissues as assesed by lipid peroxidation, seem to trigger the accumulation of leukocytes in the tissue involved, and thus cause tissue injury also indirectly through activated neutrophils. Activated neutrophils are known to induce tissue injury through the production and release of reactive oxygen metabolites and cytotoxic proteins (e.g. proteases, myeloperoxidase, lactoferrin) into the extracellular fluid. In this study we have evaluated the MPO activity as an indirect index of neutrophil infiltration and found that ACR induced oxidative damage involves the interaction of neutrophils and the protective effects of the melatonin is mediated in part by blocking tissue neutrophil infiltration. This might also result in reduced lipid peroxidation and less accumulation of MDA; since activation of neutrophils might lead to the generation of oxygene reactive metabolites (47).
In the present study, collagen contents of the hepatorenal tissues, indicating the presence of tissue fibrotic activity, were significantly increased at the ACR administration, when the neutrophil-mediated oxidative injury was also evident. In the previous studies, melatonin treatment attenuated the fibrotic activity that would proceed with hepatic and renal scarring by limiting the activation and/or accumulationof neutrophils, which have a major role in oxidative damage along with the generation of proinflammatory cytokines and $\operatorname{ROS}(48,49)$. Thus, the antioxidant melatonin might help in reducing the severity of chronic hepatorenal scarring.

In conclusion, our results demonstrate for the first time that in ACR toxicity, melatonin by inhibiting neutrophil infiltration, balancing oxidant-antioxidant status, and regulating the generation of inflammatory mediators protected the tissues and thus, supplementing with melatonin may be useful in individuals who are at risk to ACR toxicity.

\section{ACKNOWLEDGEMENT}

We would like to honor the memory of Dr. Nursal Gedik, our dear friend, who passed a way in 2007. Without her contribution, it would not be possible to accomplish the current study. This study was financially supported by Grant Project No: SAG-BGS-270605-0133 from the Commission of Scientific Investigations Projects of Marmara University.

\section{Sıçanlarda akrilamidin neden olduğu oksidatif doku hasarına karşı melatoninin koruyucu etkisi}

ÖZET: Akrilamid (ACR), vücutta oksidatif strese neden olan yaygın kullanıma sahip bir endüstriyel kimyasal maddedir. Bu çalışma ile sıçanların karaciğer ve böbreklerinde akrilamid toksisitesine karşı, antioksidan bir ajan olarak kullanılan melatoninin (MEL) olası koruyucu etkisinin araştırılması amaçlanmıştır. Çalışmamızda 200-250 gr. ağırlığında her iki cinsten Wistar albino sıçanlar kullanıldı ve her biri 6 sıçandan oluşan 4 grup oluşturuldu. Sıçanlara 10 gün boyunca; 1) \% $0.9 \mathrm{NaCl}$ ip; kontrol (C) grubu; 2) $10 \mathrm{mg} / \mathrm{kg}$ melatonin, ip (MEL); 3) $40 \mathrm{mg} / \mathrm{kg}$ akrilamid (\% $0.9 \mathrm{NaCl}$ içinde çözülmüş), ip (ACR grubu) ve 4) $10 \mathrm{mg} / \mathrm{kg}$ melatonin, ip ile birlikte $40 \mathrm{mg} / \mathbf{k g}$ Akrilamid, ip olarak uygulandı. Bu sürenin sonunda dekapitasyon edilerek, karaciğer ve böbrek dokuları çıkarıldı. Dokularda malondialdehit (MDA), glutatyon (GSH) ve kollajen düzeyleri ile myeloperoksidaz aktivitesi (MPO) incelenirken, serum örneklerinde enzim aktiviteleri ve sitokin düzeyleri ölçüldü. ACR uygulanan grupta, dokularda MDA düzeyleri, MPO aktivitesi ve kollajen içeriği oksidatif organ hasarına bağlı artarken, GSH seviyeleri ise önemli ölçüde azalmıştır. MEL uygulanan ACR grubunda ise, tüm bu oksidan yanıtların önemli ölçüde düzeldiği belirlenmiştir. ACR uygulamasını takiben önemli ölçüde artan serum enzim aktivitesi, sitokin düzeyleri ve Iökosit apoptozis MEL uygulaması ile azalmıştır. Sonuçlar ACR'e bağlı doku hasarında oksidatif mekanizmaların rolünü ve melatoninin antioksidan özellikleri ile akrilamid toksisitesine bağlı oksidatif organ hasarını düzelttiğini göstermektedir.

ANAHTAR SÖZCÜKLER: akrilamid, melatonin, lipid peroksidasyonu, glutatyon, myeloperoksidaz

\section{REFERENCES}

1. Yousef MI, El-Demerdash FM. Acrylamide-induced oxidative stress and biochemical perturbations in rats. Toxicology 2006; 219: 133-41.

2. Erdreich LS, Friedman MA. Epidemiologic evidence for assessing the carcinogenicity of acrylamide. Regul Toxicol Pharmacol 2004; 39: 150-7.

3. Tareke E, Heinze TM, Gamboa DA Costa G, Ali S. Acrylamide formed at physiological temperature as a result of asparagine oxidation. J Agric Food Chem 2009; 57: 9730-3.
4. World Health Organization, Environmental Health Criteria 49. Acrylamide. Geneva, Switzerland, 1985.

5. Vanecek J. Cellular mechanisms of melatonin action. Physio Rev 1998; 78: 687-721.

6. Ambriz-Tututi M, Rocha-González HI, Cruz SL, Granados-Soto V. Melatonin: A hormone that modulates pain. Life Sci 2009; 84: 489-98.

7. Tan DX, Chen LD, Poeggeler B, Manchester LC, Reiter RJ. Melatonin: a potent, endogenous hydroxyl radical scavenger. Endocr J 1993; 1: 57-60. 
8. Poeggeler B, Saarela S, Reiter RJ, Tan DX, Chen L-D, Manchester LC, Barlow-Walden LR. Melatonin a highly potent endogenous radical scavenger and electron donor: new aspects of the oxidation chemistry of this indole accessed in vitro. Ann NY Acad Sci 1994; 738: 419-20.

9. Pieri C, Marra M, Moroni F, Recchioni R, Marcheselli F. Melatonin: a peroxyl radical scavenger more effective than vitamin E. Life Sci 1994; 55: PL271-6.

10. Gilad E, Cuzzocrea S, Zingarelli B, Salzman AL, Szabó C. Melatonin is a scavenger of peroxynitrite. Life Sci 1997; 60: 169-74.

11. Tan DX, Poeggeler B, Reiter RJ. The pineal hormone melatonin inhibits DNA adduct formation induced by the chemical carcinogen safrole in vivo. Cancer Lett 1993; 70: 65-71.

12. Reiter RJ, Calvo JR, Karbownik M, Qi W, Tan DX. Melatonin and its relation to the immune system and inflammation. Ann NY Acad Sci 2000; 917: 376-86.

13. Rosen J, Than NN, Koch D, Poeggeler B, Laatsch $H$, Hardeland R. Interactions of melatonin and its metabolites with the ABTS cation radical: extension of the radical scavenger cascade and formation of a novel class of oxidation products, C2-substituted 3-indolinones. J Pineal Res 2006; 41: 374-81.

14. Tan DX, Manchester LC, Terron MP, Flores LJ, Reiter RJ. One molecule, many derivatives: a never-ending interaction of melatonin with reactive oxygen and nitrogen species? J Pineal Res 2007; 42: 28-42.

15. Manda K, Ueno M, Anzai K. AFMK, a melatonin metabolite, attenuates $\mathrm{X}$-ray-induced oxidative damage to DNA, proteins and lipids in mice. J Pineal Res 2007; 42: 386-93.

16. Reiter RJ, Tan DX, Acuna-Castroviejo D, Burkhardt $S$. Melatonin: mechanisms and actions as an antioxidant. Curr Topics Biophys 2000; 24: 171-83.

17. Reiter RJ, Tan DX, Manchester LC, Qi W. Biochemical reactivity of melatonin with reactive oxygen and nitrogen species. A review of the evidence. Cell Biochem Biophys 2001; 34: 237-56.

18. Talke H, Schubert, GE. Enzymatic urea determination in the blood and serum in the Warburg optical test. Klin Wochen 1965; 43: 174-75.

19. Moss DW, Henderson AR, Kachmar JF. Enzymes. In: Fundamentals of Clinical Chemistry. Tietz NW. Ed., WB Saunders Company, Philadelphia, 1987, pp.372-3.

20. Slot C. Plasma creatinine determination. A new and specific Jaffe reaction method. Scand Clin Lab Invest 1965; 17:381-7.

21. Martinek RG. A rapid ultraviolent spectrophotomeetric lactic dehydrogenase assay. Clin Chim Acta 1972; 40:91-9.

22. Beuge JA, Aust SD. Microsomal lipid peroxidation. Methods Enzymol 1978; 52: 302-11.

23. Beutler E. Glutathione in red blood cell metabolism. In A Manuel of Biochemical Methods, Grune\&Strattonb, NewYork, 1975; pp.114-22.

24. Hillegass LM, Griswold DE, Brickson B, AlbrightsonWinslow C. Assessment of myeloperoxidase activity in whole rat kidney. J Pharmacol Methods 1990; 24: 285-95.
25. Lopez De Leon A, Rojkind M. A simple micromethod for collagen and total protein determination in formalinfixed parraffin-embedded sections. J Histochem Cytochem 1985; 33: 737-43.

26. Takei $H$, Araki $A$, Watanabe $H$, Ichinose $A$, Sendo F. Rapid killing of human neutrophils by the potent activator phorbol 12-myristate 13-acetate (PMA) accompanied by changes different from typical apoptosis or necrosis. J Leukocyte Biol 1996; 59: 229-40.

27. Rayburn JR, Friedman M. L-Cysteine, N-Acetyl-1cysteine, and Glutathione Protect Xenopus laevis Embryos against Acrylamide-Induced Malformations and Mortality in the Frog Embryo Teratogenesis Assay. J Agric Food Chem. 2010; 58: 11172-8.

28. Kopp EB, Ghosh S. NF-kappa B and rel proteins in innate immunity. Adv Immunol 1995; 58: 1-27.

29. Park YC, Rimbach G, Saliou C, Valacchi G, Packer L. Activity of monomeric, dimeric, and trimeric flavonoids on NO production, TNF-alpha secretion, and NF-kappaBdependent gene expression in RAW 264.7 macrophages. FEBS Lett 2000; 465: 93-7.

30. Rezende-Neto JB, Moore EE, Melo De Andrade MV, Teixeira MM, Lisboa FA, Arantes RM, de Souza DG, da Cunha-Melo JR. Systemic inflammatory response secondary to abdominal compartment syndrome: Stage for multiple organ failure. J Trauma 2002; 53: 1121-8.

31. Radons J, Heller B, Bürkle A, Hartmann B, Rodriguez ML, Kröncke KD, Burkart V, Kolb H. Nitric oxide toxicity in islet cells involves poly(ADP-ribose) polymerase activation and concomitant NAD+ depletion. Biochem Biophys Res Commun 1994; 30: 1270-7.

32. Pacher $P$, Liaudet $L$, Mabley JG, Komjáti K, Szabó C. Pharmacologic inhibition of poly (adenosine diphosphateribose) polymerase may represent a novel therapeutic approach in chronic heart failure. J Am Coll Cardiol 2002; 40: 1006-16.

33. Dizdaroglu M. Oxidative damage to DNA in mammalian chromatin. Mutat Res 1992; 275: 331-42.

34. Shigenaga MK, Hagen TM, Ames BN. Oxidative damage and mitochondrial decay in aging. Proc Natl Acad Sci USA 1994; 91: 10771-8.

35. Stark G. Functional Consequences of Oxidative Membrane Damage. J Membrane Biol 2005; 205: 1-16.

36. Yamamoto Y. Oxidation of biological membranes and its inhibition. Free radical chain oxidation of erythrocytes ghost membranes by oxygen. Biochem Acta 1985; 819: 29-36.

37. Jaworek J, Leja-Szpak A, Nawrot-Porabka K, Bonior J, Szklarczyk J, Kot M, Konturek SJ, Tomaszewska R, Pawlik WW. Effect of neonatal endotoxemia on the pancreas of adult rats. J Physiol Pharmacol 2008; 59: 87-102.

38. El-Sokkary GH, Reiter RJ, Tan DX, Kim SJ, Cabrera J. Inhibitory effect of melatonin on products of lipid peroxidation resulting from chronic ethanol administration. Alcohol and Alcoholism 1999; 34: 842-50.

39. Kurebayashi H, Ohno Y. Metabolism of acrylamide to glycidamide and their cytotoxicity in isolated rat hepatocytes: protective effects of GSH precursors. Arch Toxicol 2006; 80: 820-8. 
40. Oliveira NG, Pingarilho $M$, Martins C, Fernandes AS, Vaz S, Martins V, Rueff J, Gaspar JF. Cytotoxicity and chromosomal aberrations induced by acrylamide in V79 cells: role of glutathione modulators. Mutat Res 2009; 676: 87-92.

41. Schulze-Osthoff $K$, Los $M$, Baeuerle PA. Redox signalling by transcription factors NF-kappa B and AP-1 in lymphocytes. Biochem Pharmacol 1995; 50: 735-41.

42. Klaunig JE, Kamendulis LM. Mechanisms of acrylamide induced rodent carcinogenesis. In: Chemistry and Safety of Acrylamide in Food; Friedman M, Mottram M Eds., Springer, New York, 2005; pp.49-62.

43. Atkuri KR, Mantovani JJ, Herzenberg LA, Herzenberg LA. N-Acetylcysteine-a safe antidote for cysteine/glutathione deficiency. Curr Opin Pharmacol 2007; 7: 355-9.

44. Friedman M. Improvement in the safety of foods by $\mathrm{SH}-$ containing amino acids and peptides. A review. J Agric Food Chem 1994; 42: 3-20.
45. Okatani Y, Wakatsuki A, Shinohara K, Kaneda C, Fukaya T. Melatonin stimulates glutathione peroxidase activity in human chorion. J Pineal Res 2001; 30: 199-205.

46. Albarran MT, Lopez-Burillo S, Pablos MI, Reiter RJ, Agapito MT. Endogenous rythms of melatonin, total antioxidant status and superoxide dismutase activity in several tissues of chick and their inhibition by light. J Pineal Res 2001; 30: 227-33.

47. Kettle AJ, Winterbourn CC. Myeloperoxidase: a key regulator of neutrophil oxidant production. Redox Report 1997; 3: 3-15.

48. Sener G, Sehirli O, Yegen BC, Cetinel S, Gedik N, Sakarcan A. Melatonin attenuates ifosfamide-induced Fanconi syndrome in rats. J Pineal Res 2004; 37: 17-25.

49. Sener G, Sert G, Sehirli AO, Arbak S, Gedik N, AyanoğluDülger G. Melatonin protects against pressure ulcer-induced oxidative injury of the skin and remote organs in rats. J Pineal Res 2006; 40: 280-7. 